\title{
ANALISIS BIAYA DAN WAKTU PROYEK PEMBANGUNAN PERUMAHAN CERME PRISMA LAND BLOK K MENGGUNAKAN METODE PERT DAN EVM (Studi Kasus: PT. Cahaya Prisma Utama)
}

\author{
Denni Aditama Eko Samsudin ${ }^{1)}$, Deny Andesta ${ }^{2)},{\text { Elly } \text { Ismiyah }^{3)}}^{3}$ \\ ${ }^{1}$ Mahasiswa Teknik Industri, Fakultas Teknik, Universitas Muhammadiyah Gresik \\ ${ }^{2,3}$ Dosen Teknik Industri, Fakultas Teknik, Universitas Muhammadiyah Gresik \\ Jl. Sumatera No.101 GKB - Gresik 61121 \\ e-mail : denniaditama11@gmail.com
}

\begin{abstract}
ABSTRAK
Dalam pelaksanaan proyek sering kali didapati proyek yang mengalami keterlambatan durasi penyelesaian dan pembengkakan biaya, oleh sebab itu penelitian ini bertujuan untuk mengevaluasi kinerja proyek pembangunan Perumahan Cerme Prisma Land PT. Cahaya Prisma Utama. Project Evaluation Review Technique (PERT) digunakan untuk mencari lintasan kritis pada proyek, lintasan kritis pada proyek ini adalah kegiatan B,C,D,E,F,G,H,K,L,S,T,V,W,Y dan AB. Earned Value Method (EVM) adalah salah satu cara untuk mengetahui perkembangan proyek dengan membentuk tiga indikator, yaitu BCWS, BCWP dan ACWP. Tujuan dari penelitian ini adalah mencari Lintasan Kritis dan mengevaluasi penyimpangan biaya (Cost) dan waktu (Time), menghitung perkiraan besarnya biaya dan waktu yang diperlukan untuk penyelesaian pengerjaan proyek. Dari hasil perhitungan berdasarkan monitoring minggu ke.13, nilai schedule variance (SV) sebesar $(-3,98 \%)$, hasil ini menunjukkan bahwa pelaksanaan pekerjaan terlambat 3,98\% dari jadwal rencana. Sedangkan cost variance (CV) sebesar $(-5,07)$, hasil ini menunjukkan pekerjaan terlaksana dengan biaya yang digunakan lebih dari anggaran. Diperkirakan waktu penyelesaian proyek $(E C D)=21$ Minggu, berarti perlu penambahan waktu selama 1 minggu, sedangkan biaya total yang diperlukan dalam penyelesaian proyek ini $($ EAC $)=$ Rp. 1.020.943.992,36 lebih besar dari anggaran yaitu sebesar Rp. 935.000.010,00.
\end{abstract}

Kata kunci : PERT, EVM, ACWP, BCWP, BCWS, SV, CV, ECD, EAC.

\section{PENDAHULUAN}

Bisnis perumahan merupakan usaha yang dilakukan oleh pengembang atau developer dengan tujuan untuk mendapatkan profit atau keuntungan sebesar-besarnya dari investasi yang telah ditanamkan. Dalam prakteknya, pengembang perumahan tidak meyelesaikan proyek perumahannya tersebut secara sendirian, tentunya membutuhkan kerjasama dengan pemberi modal atau bank untuk menyelesaikan suatu proyek. Oleh karena itu manajemen proyek sangatlah penting dalam mencapai tujuan suatu perusahaan.

Proyek adalah suatu rangkaian kegiatan sementara yang berlangsung dalam jangka waktu terbatas, dengan alokasi sumber daya tertentu dan dimaksudkan untuk melaksanakan tugas yang sasarannya telah digariskan dengan jelas (Soeharto, 1995). Dalam pelaksanaan proyek terdapat beberapa komponen penting yang menjadi penentu keberhasilan suatu proyek, atau disebut sebagai tujuan awal proyek. Komponen tersebut berupa biaya, waktu, dan mutu yang saling berkaitan satu sama lain. Ketiga komponen tersebut harus diolah sebaik mungkin untuk memperoleh keuntungan yang sesuai dengan rencana (Soeharto, 1995). Di dalam dunia industri, khususnya dibidang kontruksi banyaknya proyek yang berjalan melebihi anggaran dan jadwal yang ditetapkan merupakan indikasi bahwa terdapat sesuatu yang salah dalam pengelolaan proyek tersebut (Khamooshi dan Golafshani, 2014).

Namun dalam menjalankan usahanya, PT. Cahaya Prisma Utama belum menggunakan metode-metode yang tepat dalam merencanakan waktu dan biaya yang dibutuhkan selama periode proyek berlangsung. Selama ini perusahaan mementukan waktu yang dibutuhkan hanya 
berpedoman pada perencanaan awal dengan menggunakan metode time schedule, dimana di dalam metode tersebut melakukan perhitungan durasi pembangunan tanpa mempertimbangkan durasi waktu tersingkat (optimistic duration time), durasi waktu yang paling mungkin (most likely time) dan durasi waktu yang paling lama (pessimistice duration time). Time Schedule adalah rencana alokasi waktu untuk menyelesaikan masing-masing item pekerjaan proyek yang secara keseluruhan adalah rentang waktu yang ditetapkan untuk melaksanakan sebuah proyek. Tujuan atau manfaat pembuatan Time Schedule pada sebuah proyek konstruksi antara lain:

1. Pedoman waktu untuk pengadaan sumber daya manusia yang dibutuhkan.

2. Pedoman waktu untuk mendatangkan material yang sesuai dengan item pekerjaan yang akan dilaksanakan.

3. Pedoman waktu untuk pengadaan alatalat kerja.

4. Time Schedule juga berfungsi sebagai alat untuk mengendalikan waktu pelaksanan proyek.

5. Sebagai tolak ukur pencapaian target waktu pelaksanaan pekerjaan.

6. Time Schedule sebagai acuan untuk memulai dan mengakhiri sebuah kontrak kerja proyek konstruksi.

7. Sebagai pedoman pencapaian progres pekerjaan setiap waktu tertentu.

Akan tetapi pada time schedule PT. Cahaya Prisma Utama hanya membahas secara garis besar dari persiapan lahan sampai pembangunan dan tidak spesifik membahas mengenai progres pembangunan, akibatnya beberapa tujuan dari pembuatan time schedule tidak dapat maksimal diantaranya :

1. Pedoman waktu untuk pengadaan sumber daya manusia yang dibutuhkan.

2. Pedoman waktu untuk mendatangkan material yang sesuai dengan item pekerjaan yang akan dilaksanakan.

3. Pedoman waktu untuk pengadaan alatalat kerja.

4. Sebagai pedoman pencapaian progres pekerjaan setiap waktu tertentu.

Akibatnya perhitungan durasi waktu proyek yang dilakukan tidak efisien dan tidak menutup kemungkinan perusahaan akan mengalami keterlambatan dalam penyelesaian proyek dan pembengkakan biaya. Data keterlambatan waktu dan pembengkakan biaya proyek yang dialami oleh PT. Cahaya Prisma Utama.

Tabel 1 Keterlambatan Waktu dan Pembengkakan Biaya Proyek

\begin{tabular}{|c|c|c|c|c|c|c|}
\hline \multirow{2}{*}{ No } & \multirow{2}{*}{ Nama Proyek } & \multicolumn{2}{|c|}{ Rearass } & \multicolumn{2}{|c|}{ Realusai } & \multirow{2}{*}{$\begin{array}{l}\text { Ketertamibatas } \\
\text { \& Keragial }\end{array}$} \\
\hline & & Bulyz & Waktu & Blaya & Woktu & \\
\hline \multirow[t]{4}{*}{1} & Peabinguatal & गार & क & 845 & 105 & $-15 \mathrm{Han}$ \\
\hline & Perimahan Cerwe & futa & Hat & Juta & Hari & -56 Juta \\
\hline & Pritela I und Blok & & & & & $(0,105)$ \\
\hline & $\mathrm{Ct}+$ Unit & & & & & \\
\hline \multirow[t]{4}{*}{2} & Pembangunan & $1,65 \mathrm{M}$ & 150 & $1,7 \mathrm{M}$ & 185 & $-35 \mathrm{~km}$ \\
\hline & Perumahan Cerme & & Han & & Han & -120 Juth \\
\hline & Prima Land Blok & & & & & Q230) \\
\hline & C 30 Unit & & & & & \\
\hline \multirow[t]{6}{*}{3} & Penbangraian & 0,27 & 2 & 912 & 26 & thari \\
\hline & Perumahan Cerme & Juta & Haxi & Juta & Hari & -3 Juta \\
\hline & Privea Land Blote & & & & & \\
\hline & K17 Unit & & & & & \\
\hline & (Prosentase & & & & & \\
\hline & Proyek 94:5) & & & & & \\
\hline
\end{tabular}

Sumber : PT. Cahaya Prisma Utama

Berdasarkan data pada tabel 1.1 dimana terjadi keterlambatan waktu penyelesaian dan pembengkakan biaya dari anggaran yang direncanakan, pada Proyek Blok K terdapat 17 Unit dengan estimasi proyek dapat terselesaikan selama tiga bulan dengan tiga tukang disetiap unitnya, diproyek blok K realisasi pembangunan mengalami keterlambatan empat hari dari rencana awal yang ditetapkan oleh perusahaan yang dapat berimbas ke waktu penyelesaian proyek, keterlambatan dan pembengkakan biaya tersebut dapat mengakibatkan kerugian atau pengurangan profit dari perusahaan dan berpengaruh pada kelangsungan usaha perusahaan, maka perusahaan berharap hal tersebut tidak terjadi lagi pada proyek - proyek selanjutnya.

\section{A. Rumusan Masalah}

1 Apa saja pekerjaan kritis yang ada pada proyek pembangunan Perumahan Blok K Cerme Prisma Land?

2 Bagaimana cara mengetahui penyimpangan waktu (Time) dan biaya (Cost) yang mungkin akan terjadi selama proyek pembangunan Perumahan Blok K Cerme Prisma Land? 
3 Bagaimana mengetahui besarnya waktu dan biaya yang diperlukan untuk penyelesaian pengerjaan proyek pembangunan Perumahan Blok K Cerme Prisma Land?

\section{B. Tujuan Penelitian}

1 Menentukan pekerjaan mana saja yang termasuk kegiatan kritis pada proyek pembangunan Perumahan Blok K Cerme Prisma Land.

2 Mengevaluasi penyimpangan waktu (Time) dan biaya (Cost) yang mungkin akan terjadi selama proyek pembangunan Perumahan Blok K Cerme Prisma Land.

3 Menghitung besaran waktu dan biaya yang diperlukan untuk penyelesaian pengerjaan proyek pembangunan Perumahan Blok K Cerme Prisma Land.

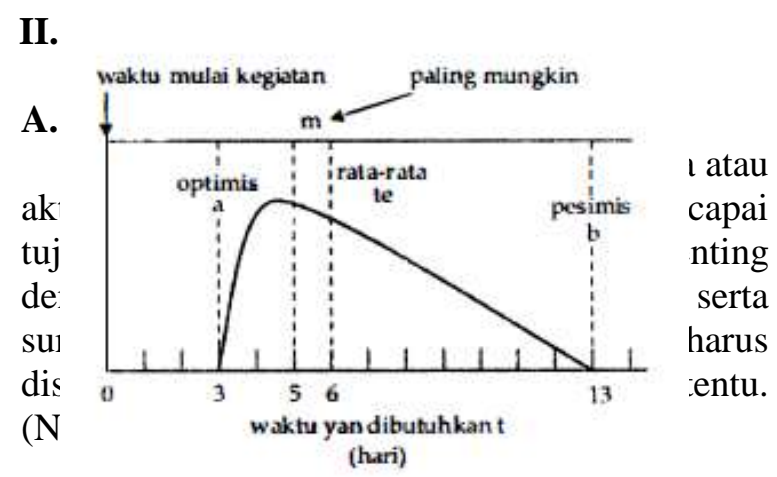

\section{Manajemen Proyek}

Handoko (1999:98) menyatakan tujuan manajemen proyek adalah sebagai berikut :

a. Tepat waktu (on time) yaitu waktu atau jadwal yang merupakan salah satu sasaran proyek, keterlambatan akan mengakibatkan kerugian, seperti penambahan biaya, kehilangan kesempatan produk memasuki pasar.

b. Tepat anggaran (on budget) yaitu biaya yang harus dikeluarkan sesuai dengan anggaran yang telah ditetapkan.

c. Tepat spesifikasi (on specification) dimana proyek harus sesuai dengan spesifikasi yang telah ditetapkan.

\section{B. Project Evaluation and Review Technique (PERT)}

PERT digunakan untuk proyek-proyek yang baru dilaksanakan untuk pertama kali, di mana estimasi waktu lebih ditekankan dari pada biayanya. Ciri utama PERT adalah adanya tiga perkiraan waktu: waktu pesimis (b), waktu paling mungkin (m), dan waktu optimis (a). Ketiga waktu perkiraan itu selanjutnya digunakan untuk menghitung waktu yang diharapkan (expected time) . Waktu optimis, a, adalah waktu minimum dari suatu kegiatan, dimana segala sesuatu akan berjalan baik, sangat kecil kemungkinan kegiatan selesai sebelum waktu ini. Waktu paling mungkin, m, adalah waktu normal untuk menyelesaikan kegiatan. Waktu ini paling sering terjadi seandainya kegiatannya bias diulang. Sedangkan waktu pesimis, b, adalah waktu maksimal yang diperlukan suatu kegiatan, situasi ini terjadi bila nasib buruk terjadi (Budi Santosa, 2009).

Gambar 1 Grafik waktu a, m dan b

Berdasarkan distribusi ini, waktu rata-rata atau waktu yang diharapkan te, untuk setiap kegiatan dapat dihitung degan rumus : (Budi Santosa, 2009)

$$
\mathrm{TE}=\frac{\mathrm{a}+4 \mathrm{~m}+\mathrm{b}}{6}
$$

\section{Penyusunan Jaringan Kerja PERT}

Diagram jaringan terdiri dari beberapa titik (notes) yang mempresentasikan kejadian (event) (Hari Handoko, 1993). Titik-titik tersebut dihubungkan oleh suatu vektor (garis yang memiliki arah) yang mempersentasikan suatu pekerjaan (task) dalam sebuah proyek. Arah dari garis menunjukan suatu urutan pekerjaan. Ada dua pendekatan dalam hal menggarnbarkan diagram jaringan kerja, yang pertama, kegiatan 
digambarkan dengan simpul (node), Activity On Node (AON). Sedangkan peristiwa atau event, diwakili oleh anak panah. Yang kedua aktivitas digambarkan dengan anak panah, Activity On Arch (AOA) (Budi Santosa, 2009).

\section{Penentuan Waktu}

Untuk menentukan jadwal proyek, harus dihitung dua waktu awal dan akhir untuk setiap kegiatan. Adapun dua waktu awal dan dua waktu akhir yaitu:

1. Earliest Start (ES) : earliest start atau mulai terdahulu adalah waktu paling awal dimana suatu kegiatan sudah dapat dimulai, dengan asumsi semua kegiatan pendahulu atau semua kegiatan yang mengawalinya sudah selesai dikerjakan.

2. Earliest Finish (EF) : earliest finish atau selesai terdahulu adalah waktu paling awal suatu kegiatan dapat selesai.

3. Latest Start (LS) : latest start atau mulai terakhir adalah waktu terakhir suatu kegiatan dapat dimulai sehingga tidak menunda waktu penyelesaian keseluruhan proyek. Latest start menunjukkan waktu toleransi terakhir dimana suatu kegiatan harus mulai dilakukan.

4. Latest Finish (LF) : latest finish atau selesai terakhir adalah waktu toleransi terakhir suatu kegiatan harus dapat selesai sehingga tidak menunda waktu penyelesaian kegiatan berikutnya dan keseluruhan proyek (Febrianto, 2011).

\section{Lintasan Kritis}

Lintasan kritis adalah lintasan sepanjang diagram jaring yang mempunyai waktu terpanjang (durasi proyek). Lintasan kritis merupakan lintasan yang melalui kegiatankegiatan yang tidak mempunyai float (waktu jeda).

Kegunaan jalur kritis adalah untuk mengetahui kegiatan mana yang memiliki kepekaan sangat tinggi atas keterlambatan penyelesaian pekerjaan, atau disebut juga kegiatan kritis. Apabila kegiatan keterlambatan proyek maka akan memperambat penyelesaian proyek secara keseluruhan meskipun kegiatan lain tidak mengalami keterlambatan. Untuk menentukan lintasan kritis dari jaringan kerja dapat dilakukan dengan dua cara yaitu :
- Lintasan kritis adalah lintasan yang melalui kegiatan-kegiatan yang mempunyai jumlah durasi terbesar.

- Dengan menghitung kegiatan-kegiatan yang mempunyai nilai Total Float $=0$

\section{Total Float (TF)}

Total Float adalah selisih antara waktu yang tersedia untuk melakukan kegiatan dengan waktu yang diperlukan untuk melakukan kegiatan tersebut (D). Waktu mulai dari suatu aktivitas/ kegiatan sekaligus menjadi waktu selesai dari aktivitas sebelumnya yang menuju ke simpul yang sama, atau secara metematis:

Dimana :

TF = LF-ES-D (Budi Santosa, 2009).

$$
\begin{array}{ll}
\text { LF } & \text { : Latest Finish } \\
\text { ES } & : \text { Earliest Start } \\
\text { D } & \text { : Durasi }
\end{array}
$$

\section{Free Float (FF)}

Free float untuk suatu kegiatan adalah waktu yang tersisa bila suatu Kegiatan dilaksanakan pada waktu yang paling awal, begitu juga kegiatan yang mengikutinya, atau: $\mathrm{FF}=$ (Waktu paling awal dari kegiatan yang mengikuti kegiatan L)-(Waktu paling awal dari kegiatan $\mathrm{L})=$ Waktu yang diperlukan $\mathrm{L}$

Dimana :

FF = EF-ES-D (Budi Santosa, 2009).

$$
\begin{array}{ll}
\text { EF } & : \text { Earliest Finish } \\
\text { ES } & : \text { Earliest Start } \\
\text { D } & : \text { Durasi }
\end{array}
$$

\section{Earned Value (Nilai Hasil)}

Menurut Soeharto (1995) konsep dasar nilai hasil dapat digunakan untuk menganalisis kinerja dan membuat prakiraan pencapaian sasaran. Untuk itu digunakan 3 indikator, yaitu actual cost of work performed (ACWP), budgeted cost of work performed (BCWP), dan budgeted cost of work scheduled (BCWS).

\section{BCWS}

Budgeted cost of work scheduled (BCWS) adalah sama dengan anggaran untuk suatu paket pekerjaan, tetapi disusun dan dikaitkan dengan jadwal pelaksanaan. Jadi di sini terjadi perpaduan antara biaya, terjadi perpaduan antara biaya, jadwal, dan lingkup kerja, di mana pada setiap elemen pekerjaan telah diberi alokasi biaya dan jadwal yang 
dapat menjadi tolok ukur dalam pelaksanaan pekerjaan (Soeharto, 1995).

\section{ACWP}

Actual cost of work performed (ACWP) adalah jumlah biaya aktual dari pekerjaan yang telah dilaksanakan. Biaya ini diperoleh dari data-data akuntansi atau keuangan proyek pada tanggal pelaporan (misalnya akhir bulan), yaitu catatan segala pengeluaran biaya aktual dari paket kerja atau kode akuntansi termasuk perhitungan overhead dan lain-lain. Jadi, ACWP merupakan jumlah aktual dari pengeluaran atau dana yang digunakan untuk melaksanakan pekerjaan pada kurun waktu tertentu (Soeharto, 1995).

\section{BCWP}

Budgeted cost of work performed (BCWP) adalah indikator yang menunjukkan nilai hasil dari sudut pandang nilai pekerjaan yang telah diselesaikan terhadap anggaran yang disediakan untuk melaksanakan pekerjaan tersebut. Bila angka Actual cost of work performed (ACWP) dibandingkan dengan BCWP, akan terlihat perbandingan antara biaya yang telah dikeluarkan untuk pekerjaan yang telah terlaksana terhadap biaya yang seharusnya dikeluarkan untuk maksud tersebut (Soeharto, 1995).

Gambar 2 Grafik Earned Value

\section{a. Cost Variance (CV)}

Cost Variance atau varian biaya merupakan selisih antara biaya yang dianggarkan untuk pekerjaan yang sudah dikerjakan Budgeted Cost of Work Performed (BCWP) dengan biaya aktual dari pekerjaan yang sudah dikerjakan Actual Cost of Work Performed (ACWP) .

$$
\mathrm{CV}=\mathrm{BCWP}-\mathrm{ACWP}
$$

$\mathrm{CV}=0$; biaya proyek sesuai rencana

$\mathrm{CV}>0$; biaya lebih kecil dari rencana

$\mathrm{CV}<0$; biaya lebih besar dari rencana

b. Schedule Variance (SV)

Schedule Variance atau varian jadwal ini merupakan pengurangan biaya yang dianggarkan untuk pekerjaan yang sudah dilaksanakan Budgeted Cost of Work Performed (BCWP) dengan biaya yang dianggarkan untuk pekerjaan yang dijadwalkan Budgeted Cost of Work Scheduled (BCWS).

$$
\mathrm{SV}=\mathrm{BCWP}-\mathrm{BCWS}
$$

$\mathrm{SV}=0$; proyek tepat waktu.

$\mathrm{SV}>0$; proyek lebih cepat.

$\mathrm{SV}<0$; proyek terlambat.

c. Cost Performance Index (CPI)

Indeks ini merupakan perbandingan antara biaya yang dianggarkan dengan biaya actual (Budi Santosa, 2009).

$$
\text { CPI = BCWP / ACWP }
$$

$\mathrm{CPI}=0$; biaya proyek sesuai rencana

CPI $>0$; biaya lebih kecil dari rencana

$\mathrm{CPI}<0$; biaya lebih besar dari rencana

\section{d. Schedule Performance Index (SPI)}

Indeks ini merupakan perbandingan biaya dari pekerjaan yang telah dilaksanakan dengan biaya dari pekerjaan yang dijadwalkan (Budi Santosa, 2009).

$$
\mathrm{SPI}=\mathrm{BCWP} / \mathrm{BCWS}
$$

$$
\begin{aligned}
& \text { घara } \mathrm{SV}=0 ; ; \text { proyek tepat waktu. } \\
& \mathrm{SV}>0 \text {; proyek lebih cepat: } \\
& { }^{120} \mathrm{SV}<0 \text {; proyek terlambat. } \\
& \text { no. } \\
& \text { e. Estimate to Coniplete (ETC) } \\
& \text { Perkiraan waktu untuk pekerjaan } \rightarrow \underset{c}{\rightarrow 0 \times w} \\
& \text { tersisa (Estimate To Completion) Audalah } \\
& \text { perkìraan jadwal pekerjaan tersisa proyek } \\
& \text { (Budit Santosa, 2009).. ETC dapat dihitung } \\
& \text { dengan rumus sebagai berikut: , , шакти }
\end{aligned}
$$

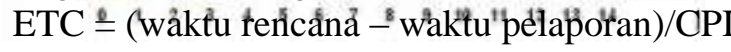

$$
\begin{aligned}
& \mathrm{ETC}=(\mathrm{BAC}-\mathrm{BCWP}) / \mathrm{CPI}
\end{aligned}
$$

\section{f. Estimate at Complete (EAC)}

Perkiraan total biaya proyek = biaya yang sudah dihabiskan + perkiraan biaya untuk pekerjaan tersisa (Budi Santosa, 2009).

$$
\mathrm{EAC}=\mathrm{ACWP}+\mathrm{ETC}
$$

\section{g. Estimate Completion Date (ECD)}


Perkiraan waktu penyelesaian proyek. ECD dapat dihitung dengan menggunakan rumus berikut.

$$
\begin{gathered}
\mathrm{ECD}=(\text { Sisa waktu } / \text { SPI })+\text { Waktu yang } \\
\text { telah dilalui }
\end{gathered}
$$

\section{METODOLOGI PENELITIAN}

Metode penelitian merupakan tahapan penelitian yang dilakukan untuk menyelesaikan suatu masalah, sehingga penelitian sangat membantu untuk mengarahkan dalam menjawab permasalahan yang ada. Metode yang digunakan untuk menentukan Durasi proyek yang optimal dapat diperoleh dari Project Evaluation and Review Technique (PERT) Sedangkan untuk pengendalian biaya dan waktu dengan menggunakan metode Earned Value Method (EVM).

\begin{tabular}{|c|c|c|c|c|c|}
\hline & Pekerjaan Atap dan Plafond & & & & \\
\hline 1 & Pasang rangka atap Hollow Galvalum & 12 & 15 & 18. & 15 \\
\hline 2 & Pas. Spandek & 9 & 11 & 13. & 11 \\
\hline 3 & Pasang hastplank GRC $20 \mathrm{~cm}$ & 5 & 6 & 7 & 6 \\
\hline 4 & Plafond Gybsum + rangica bollow & 9 & 11 & 13 & 11 \\
\hline \multirow[t]{2}{*}{5} & List Plafond Gybsum Scm & 6 & 7 & 8 & 7 \\
\hline & Pekerjaan Peugecatan & & & & \\
\hline 1 & Cat tembok exterior \& interior & 8 & 10 & 12 & 10 \\
\hline 2 & Cat piafond & 7 & 8 & 9 & 8 \\
\hline 3 & Cat kusen, daun pintu \& jendela & 5 & 7 & 9 & 7 \\
\hline \multirow[t]{2}{*}{4} & Cat lisplank & 3 & 4 & 5 & 4 \\
\hline & Pekerjaan Lain-lain & & & & \\
\hline 1 & Pembersithan & 4 & 5 & 6 & 5 \\
\hline
\end{tabular}

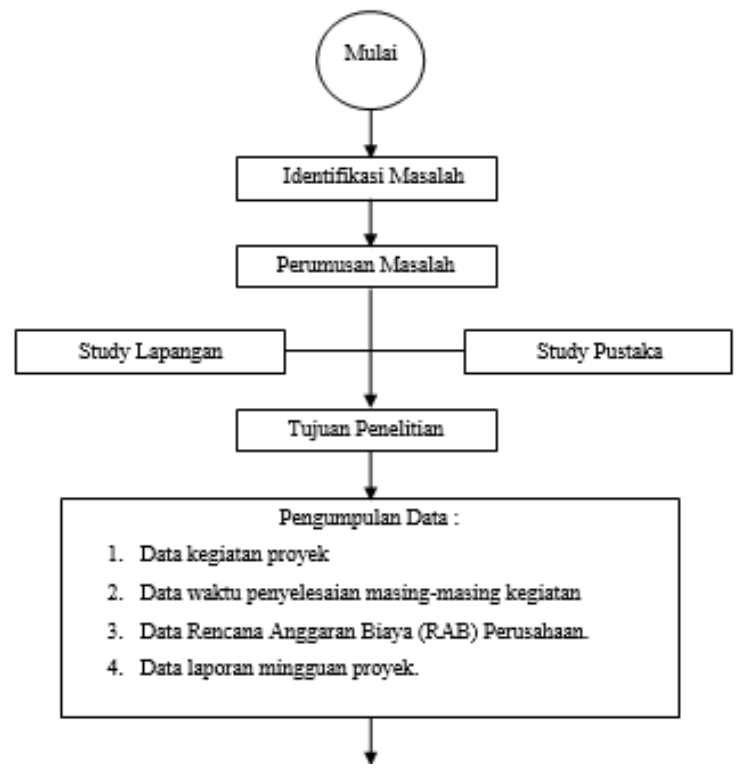

\section{HASIL DAN PEMBAHASAN}

\section{A. PERT (Project Evaluation and Review Technique)}

Hasil perhitungan waktu Expected Time (ET) dari pengolahan data dengan metode Project Evaluation and Review Technique (PERT) ditampilkan pada Tabel 2 sebagai berikut :

Tabel 2 Pengumpulan data waktu

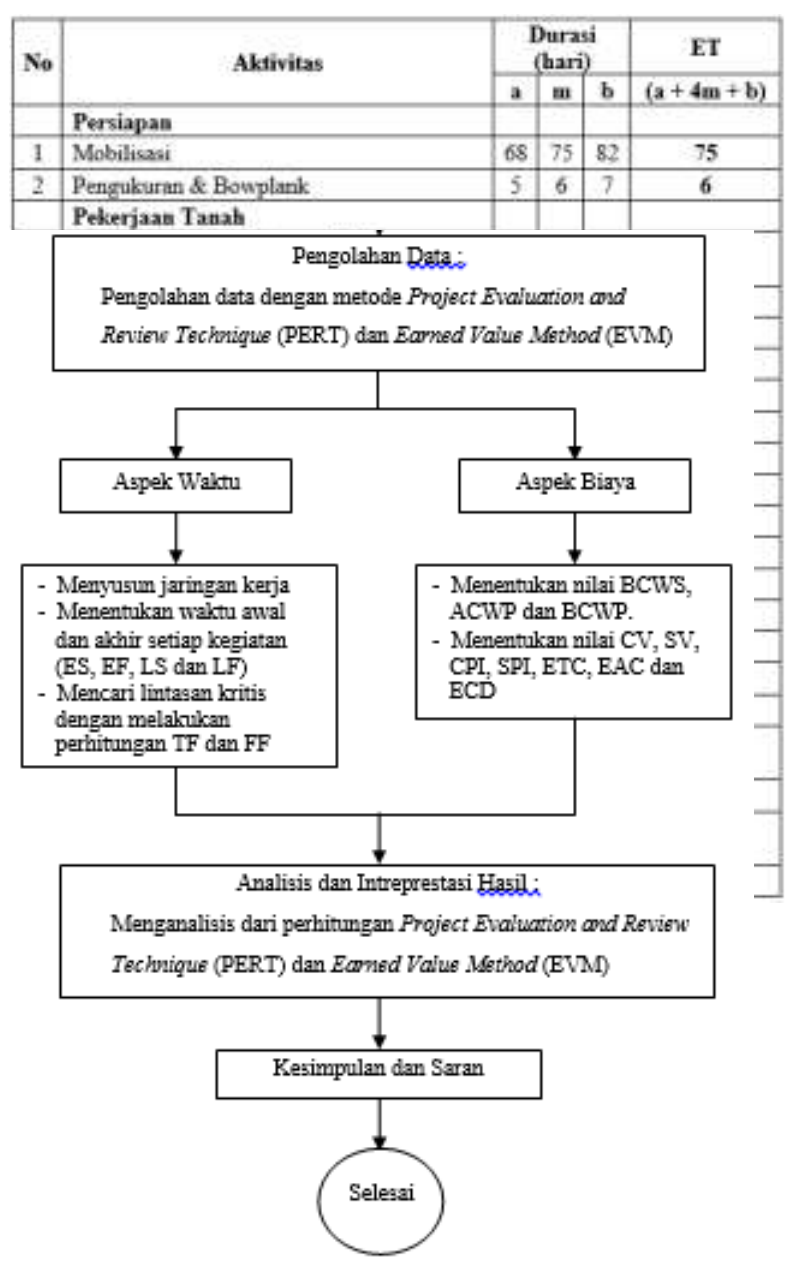


Dari tabel tersebut didapat pengumpulan data waktu penyelesaian masing-masing kegiatan, pengumpulan data yang dimaksud ialah pengumpulan tiga perkiraan waktu: waktu optimis (a), waktu paling mungkin (m) dan waktu pesimis (b). Ketiga waktu tersebut didapat pimpinan proyek, berdasarkan data yang didapat pada PT. Cahaya Prisma Utama. Setelah mendapat data kegiatan proyek dimulai, sampai kegiatan proyek pembangunan perumahan Cerme Prisma Land berakhir maka tahapan selanjutnya yaitu menghitung nilai ET.

$$
\mathrm{ET}=\frac{\mathrm{a}+4 \mathrm{~m}+\mathrm{b}}{6}
$$

$$
\begin{aligned}
& \text { a. } \mathrm{ET}=\frac{\frac{68+(4 \times 75)+}{6}}{\frac{82}{6}}=\frac{450}{6}=75 \\
& \text { ab. } \mathrm{ET}=\frac{4+(4 \times 5)+6}{6}=\frac{30}{6}=5
\end{aligned}
$$

Tabel 3 Total float (TF) dan Free float (FF)

Dari tabel tersebut dapat ditampilkan data Earliest Start, Earliest Finish, Latest Start dan Latest Finish, langkah selanjutnya adalah menghitung Total float (TF) dan Free float $(F F)$. Hasil perhitungan tersebut, diperoleh kegiatan kritis pada Proyek Pembangunan Perumahan Blok K Cerme Prisma Land PT Cahaya Prisma Utama. Lintasan kritis pada proyek perumahan blok K Cerme Prisma Utama adalah B, C, D, E, F, G, H, K, L, S, T, V, W, Y dan AB (kolom

\begin{tabular}{|c|c|c|c|c|c|c|}
\hline \multirow{2}{*}{$\begin{array}{c}\text { Minggu } \\
\text { ke- }\end{array}$} & \multirow{2}{*}{ Tanggal } & \multirow{2}{*}{$\begin{array}{l}\text { BAC } \\
\text { (Rp) }\end{array}$} & \multicolumn{2}{|c|}{$\begin{array}{c}\text { Bebet } \\
\text { BCWS (\%) }\end{array}$} & \multicolumn{2}{|c|}{ BCWS (Rp) } \\
\hline & & & Ming & Kom & Mingzuan & Komulatif \\
\hline 1 & 25-03 Miret. & \multirow{20}{*}{ 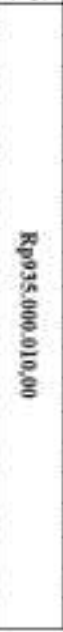 } & 1,67 & 1,67 & Rp15.614.500,17 & Rp15.614.500,17 \\
\hline 2 & 04-10 Maret & & 0,81 & 2,48 & Rp7.573.500,08 & Rp23.188.000,25 \\
\hline 3 & 11-17 Maret & & 6.6 & 9.08 & Rpo1.710.000,06 & Rp54.898.000,91 \\
\hline 4 & 18.24 Maret & & 6,24 & 15,32 & Rp58.344.000,62 & Rpl43.242.001,53 \\
\hline 5 & 25-31 Maret & & 5,8 & 21,12 & $R_{p} 54,230,000,58$ & $R_{p} 197,472.002,11$ \\
\hline 6 & $01-0 ?$ & & 6,33 & 27,45 & Rp59.185,500,63 & $R_{p} 256.657 .502,75$ \\
\hline 7 & 08-14 April & & 0,24 & 33,69 & $R_{p} \leq 8.344 .000,62$ & Rp315.001.503,37 \\
\hline 8 & 15.21 April & & 3,07 & 36,76 & Rp28.704.500,31 & Rp343,706,003,68 \\
\hline 9 & 22-28 April & & 4,21 & 40,97 & Rp39,363500,42 & Rp383,060,504,10 \\
\hline 10 & $29-05 \mathrm{Mei}$ & & 3,61 & 44,58 & Rp33.753,500,36 & $R_{p} 416.823 .004 .46$ \\
\hline 11 & $06-12 \mathrm{Mei}$ & & 5,24 & 49,82 & Rp48,994,000,52 & Rpt65.817.004.98 \\
\hline 12 & 13-19 Mei & & 4,72 & 54,54 & Rpt4.132:000,47 & Rp509.949.005,45 \\
\hline 13 & $20-26 \mathrm{MeI}$ & & 4,45 & 58,99 & Rpt1.607.500,45 & $R p 551.556 .505,90$ \\
\hline 14 & 27-01 Juni & & 6,1 & 65,09 & Rp57.035.000,61 & Rp608.591.505.51 \\
\hline 15 & $10-16$ Juni & & 4,55 & 69,04 & $R p+2.542 .500,40$ & Rp651:134,000,96 \\
\hline 16 & 17.23 Jani & & 6,55 & 76,19 & Rpo $1.242 .500,66$ & Rp 712.376 .507 .02 \\
\hline 17 & $24-30$ Juni & & 6,71 & 82,9 & $\mathrm{Rp} 62.738,500,67$ & $R_{p} 775,115,008,29$ \\
\hline 18 & 01-07 Juli & & 7.25 & 90,15 & Kp67.787.500,73 & $R p 842.902,509,02$ \\
\hline 19 & 08-14 Juili & & 5,45 & 95,6 & Rp50.957.500,55 & Rp\$93.860.009,50 \\
\hline 20 & 15-21 Jah & & 4,4 & 100 & Rp41.140.000,44 & Rp935,000,010,00 \\
\hline
\end{tabular}
berwarna biru tabel 3).
Tabel 4 Nilai BCWS per Minggu

Nilai dari BCWS proyek untuk setiap biaya yang dikeluarkan telah ditentukan oleh perusahaan. Nilai BCWP yang digunakan ditunjukan dalam tabel 4.

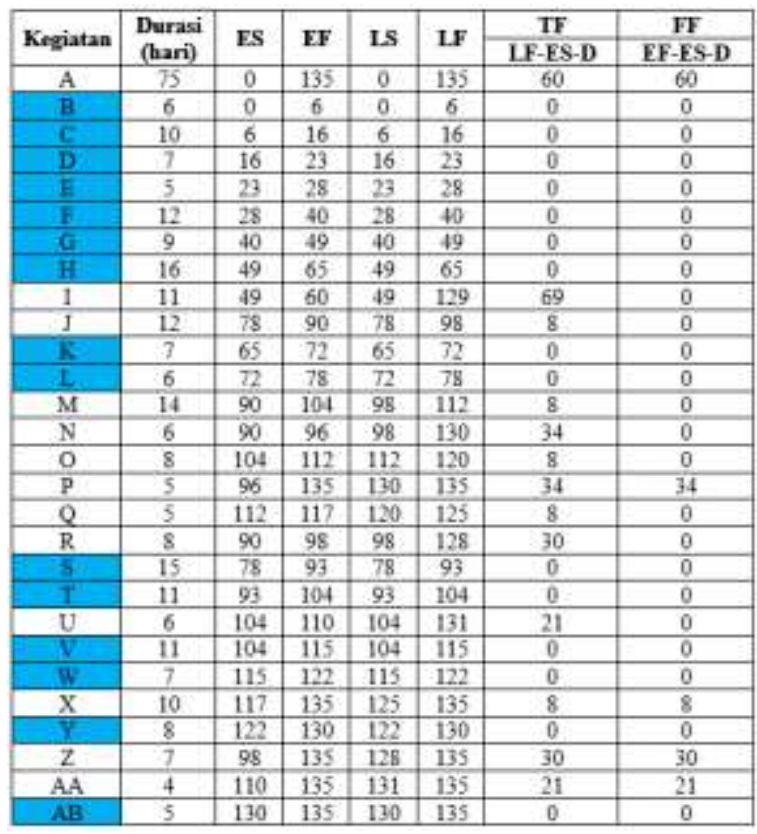

Tabel 5 Nilai BCWP per Minggu

\section{B. EVM}




\begin{tabular}{|c|c|c|c|c|c|c|}
\hline \multirow{2}{*}{$\begin{array}{c}\text { Mfinggu } \\
\text { ke }\end{array}$} & \multirow{2}{*}{ Tangal } & \multirow{2}{*}{$\begin{array}{l}\text { BAC } \\
\text { (Rp) }\end{array}$} & \multicolumn{2}{|c|}{$\begin{array}{c}\text { Bobot } \\
\text { BCWP }(\%)\end{array}$} & \multicolumn{2}{|c|}{$B C W P\left(R_{p}\right)$} \\
\hline & & & Ming & Kom & Mfingeruan & Komulatif \\
\hline$t$ & wet & \multirow{13}{*}{ 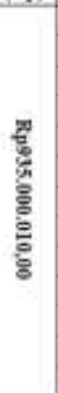 } & 0,52 & 0,52 & Rp4,862 000,05 & Rpt $\$ 62.000,05$ \\
\hline 2 & & & 1,71 & 2,23 & $R p 15988,500,17$ & $p 20.850 .500,22$ \\
\hline 3 & & & 6,5 & 8,73 & Rp60.775,000,65 & Rp51.625.500,\$7 \\
\hline 4 & & & 4,48 & 13,21 & Rpt1,88s 000,45 & Rp123,513.501,32 \\
\hline 5 & $25.31 \mathrm{M}$ & & 5,25 & 18,46 & Rp49087,500,53 & Rpl72.601.001.85 \\
\hline 6 & & & 7,99 & 26,45 & $\mathbb{R p 7 4 . 7 0 6 , 5 0 0 , 8 0}$ & Rp247,307,502,65 \\
\hline$T$ & & & 6,24 & 32,69 & Rp58.344,000,62 & Rp305,651.503,27 \\
\hline 8 & 15-21 April & & 3,49 & 36,18 & $R_{p} 32631500,35$ & Rp336 \\
\hline 9 & 22.28 April & & 5,07 & 41,25 & $R_{047,404,300,51}$ & Rpj855687.504,13 \\
\hline 10 & $29-05 \mathrm{Mei}$ & & 2,91 & 44,16 & $R_{p 2} 27,208.500,29$ & Rpt12.896.004,42 \\
\hline $\mathrm{tt}$ & & & 3,37 & 47,53 & $R p 31509,500,34$ & Rpl44.405.504,75 \\
\hline 12 & & & 4,53 & 52,06 & $R p 42.355,500,45$ & Rp $186.761,005,21$ \\
\hline 13 & $20-26 \mathrm{Mer}$ & & 2.95 & 55,01 & $R_{p 27582500,30}$ & Rpsi4 343.505,50 \\
\hline
\end{tabular}

BCWP merupakan nilai yang diterima dari penyelesaian pekerjaan selama periode waktu tertentu, BCWP inilah yang disebut Earned Value. Nilai BCWP dalam penelitian ini diperoleh dari stockopname setiap minggu yang diperoleh dari PT. Cahaya Prisma Utama. Nilai BCWP dari proyek adalah seperti berikut ini, sedangkan nilai ACWP ditampilkan dalam tabel 6.

Tabel 6 Nilai ACWP per Minggu

\begin{tabular}{|c|c|c|c|c|c|c|}
\hline \multirow{2}{*}{$\begin{array}{c}\text { Mlinggu } \\
\text { ke- }\end{array}$} & \multirow{2}{*}{ Tangeal } & \multirow{2}{*}{\begin{tabular}{|l} 
BAC \\
(Kp)
\end{tabular}} & \multicolumn{2}{|c|}{$A C W P(R p)$} & \multicolumn{2}{|c|}{$\begin{array}{c}\text { Bebot } \\
\text { ACWP (\%) }\end{array}$} \\
\hline & & & Mingguas & Komulatif & Mitag & Kom \\
\hline 1 & colveret & \multirow{13}{*}{$\begin{array}{l}\frac{\pi}{0} \\
\text { yू } \\
\text { हू } \\
\text { है } \\
\text { है } \\
\text { है }\end{array}$} & $R_{p} 4.500,000,00$ & Rot $500,000,00$ & 0.48 & 0,48 \\
\hline 2 & 04-10 Mares & & Rp10.750.000,00 & $R 015,250,000,00$ & 1.15 & 1.63 \\
\hline 3 & -17 Maret & & Rqp55.000.000,00 & $\mathbb{R} 970.250,000,00$ & 5,88 & 7,51 \\
\hline 4 & 18-24 Matet & & Rp42.250.000,00 & $R p 112.500,000,00$ & 4,52 & 1203 \\
\hline 5 & 25-31 Maret & & Rp115,500,000,00 & $R p 226000000000$ & 12,14 & 24,17 \\
\hline 6 & $01-07$ April & & Rpo0 $500,000,00$ & Rp2 $285,500,000,00$ & 6,47 & 30,64 \\
\hline 7 & 08-14 April & & Rp $47500,000,00$ & $R_{p} 334,000,000,00$ & 5,05 & 35,72 \\
\hline 8 & 15-21 April & & Rp25:025:000,00 & $R p 359,025,000,00$ & 2,58 & 38,40 \\
\hline 9 & 22-28 April & & Rp50.775.000,00 & Rpt00 $\$ 00000,00$ & 5,43 & 43,83 \\
\hline 10 & $29-05 \mathrm{Mei}$ & & $R_{p} 27,200,000,00$ & $R p 437,000,000,00$ & 2,91 & 46,74 \\
\hline 11 & $06-12 \mathrm{Mer}$ & & $R_{p} 30,755,000,00$ & Rep407,755,000,00 & 3,29 & $\$ 0,03$ \\
\hline 12 & $13-19 \mathrm{Met}$ & & $R p 52.550 .000,00$ & $R p 500305000,00$ & 3,48 & 53.51 \\
\hline 13 & $20-26 \mathrm{Met}$ & & Rp61.407.000,00 & Rp561.712.000,00 & 6.57 & 60,00 \\
\hline
\end{tabular}

Analisa Schedule Variance dan Cost Variance

Tabel 7 Analisa $S V$ dan $C V$

\begin{tabular}{|c|c|c|c|c|c|c|}
\hline \multirow{2}{*}{ Tanggal } & $\mathrm{CV}$ & $\mathrm{CV}$ & \multirow[b]{2}{*}{ CPI } & Sv & Sv & SPI \\
\hline & (Rp) & (\%) & & (Rp) & (\%) & (\%) \\
\hline 25-03 Maret & -Rp4.857.999,95 & $-0,52$ & 0,499 & -Rp10 752.500,12 & $-1,15$ & 0,311 \\
\hline 04-10 Maret & -Rp7.106.499.78 & $-0,76$ & 0,746 & $-R p 2.337,500,03$ & -0.25 & 0.899 \\
\hline $11-17$ & Rp5968.500.87 & 0,64 & 1,079 & $-\operatorname{Rp} 3.232 .500,04$ & $-0,35$ & 0,961 \\
\hline 18 & $-\operatorname{Rp} 739$ & $-0,79$ & 0,944 & Rp19.728 & $-2,11$ & 0,862 \\
\hline $25-3$ & $-R p 33,305998,15$ & $-3,56$ & 0,838 & $-\operatorname{Rp} 24871.000,27$ & $-2,66$ & 0.874 \\
\hline $01-0$ & -Rp19,099,497,36 & $-2,04$ & 0,928 & $-R p 9.350 .0$ & $-1,00$ & 0,964 \\
\hline & Rp8.255,496,73 & $-0,88$ & 0,974 & $\operatorname{Rp9.350,00}$ & $-1,00$ & 0,970 \\
\hline 15-21 April & $\mathrm{Rp} 20.648,996,38$ & $-2,21$ & 0,942 & $R 55.423 .000,06$ & $-0,58$ & 0,984 \\
\hline 22.28 April & $-\operatorname{Rp} 24,019,495,88$ & $-2,57$ & 0,941 & Rp2,618.000,03 & 0,28 & 1,007 \\
\hline & $-\operatorname{Rp} 24,060995,58$ & $-2,57$ & 0,945 & Rp3927,000,04 & $-0,42$ & 0,991 \\
\hline $06-12 \mathrm{Mei}$ & $\operatorname{Rp} 23,306,495,25$ & $.2,49$ & 0,950 & Rp21.411.500,23 & $-2,29$ & 0,954 \\
\hline $13-19 \mathrm{Mei}$ & $-\operatorname{Rg} 13,500,994,79$ & $-1,44$ & 0,973 & $-\operatorname{Rp} 23.188 .000,25$ & $-2,48$ & 0,955 \\
\hline $20-26 \mathrm{Mei}$ & $-\operatorname{Re} 47,368.494,50$ & $-5,07$ & 0,910 & $-R p 37213.000,40$ & $-3,98$ & 0,933 \\
\hline
\end{tabular}

Dari hasil perhitungan diatas dapat diketahui bahwa sampai minggu ke-13 penyimpangan jadwal pekerjaan atau Schedule Variance (SV) sebesar $(-3,98)$. Hasil ini menunjukkan bahwa pelaksanaan pekerjaan terlambat 3,98 dari jadwal yang telah direncanakan. Sedangkan hasil perhitungan indeks kinerja waktu atau Schedule Performance Index (SPI) sebesar 0,933 Nilai ini menunjukkan bahwa nilai SPI $<1$, artinya penyelengaraan proyek lebih lambat dari perencanaan, dapat dilihat pada grafik indeks kinerja waktu (SPI) pada gambar 4.

Dari hasil perhitungan diatas dapat diketahui bahwa sampai minggu ke-13 penyimpangan biaya pekerjaan atau Cost Variance (CV) sebesar (-5,07). Hasil ini menunjukkan pelaksanaan terlaksana dengan biaya yang digunakan lebih dari anggaran atau lebih besar daripada biaya yang sebelumnya telah direncanakan. Sedangkan hasil perhitungan indeks kinerja biaya atau Cost Performance Index (CPI) sebesar 0,916 Nilai ini menunjukkan bahwa nilai CPI $<1$, artinya pengeluaran lebih besar dari anggaran yang direncanakan, dapat dilihat pada grafik indeks kinerja biaya (CPI) pada gambar 5 .

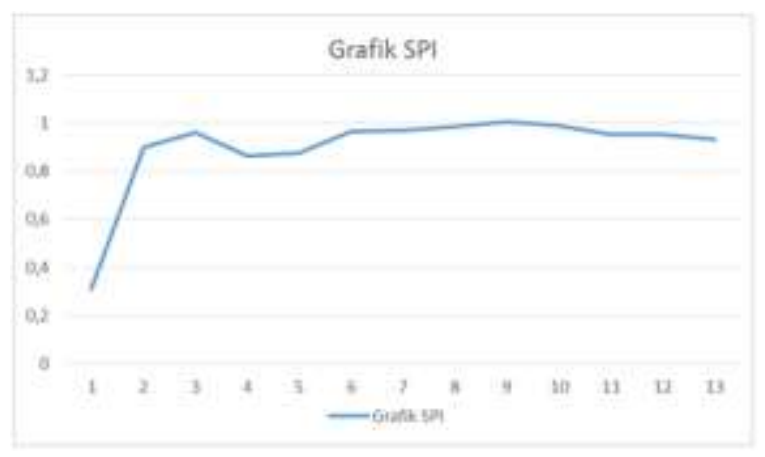

Gambar 4 Grafik Schedule Performance Index 


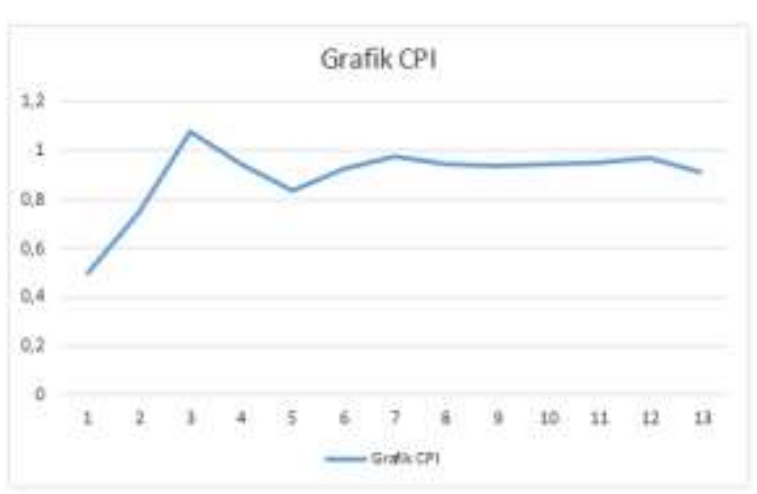

Gambar 5 Grafik Cost Performance Index

Berdasarkan hasil perhitungan tersebut, dapat diketahui perkiraan waktu penyelesaian proyek atau Estimated at Compleation Date (ECD).

Waktu yang telah dilalui $\quad=13$ Minggu

Sisa waktu pelaksanaan $\quad=7$ Minggu

$$
\begin{aligned}
& \text { ECD }=(\text { Sisa waktu / SPI })+\text { Waktu yang } \\
& \text { telah dilalui. } \\
&=(7 / 0,916)+13 \\
&=21 \text { Minggu (Berarti perlu } \\
& \text { penambahan waktu selama } 1 \\
& \text { minggu, dimana penyelesaian } \\
& \text { proyek pada perencanaan } \\
& \text { membutuhkan waktu selama } 20 \\
& \text { minggu) }
\end{aligned}
$$

Estimated To Complete (ETC) atau perkiraan biaya untuk pekerjaan tersisa.

$$
\begin{aligned}
\mathrm{ETC} & =(\mathrm{BAC}-\mathrm{BCWP} / \mathrm{CPI}) \\
& =(\operatorname{Rp} 935.000 .010,00-\mathrm{Rp} \\
& 514.343 .505,50 / 0,916) \\
& =\operatorname{Rp} 459.231 .992,36
\end{aligned}
$$

Estimated At Complete (EAC) atau perkiraan biaya pada saat penyelesaian proyek.

$$
\begin{aligned}
\mathrm{EAC} & =\mathrm{ETC}+\mathrm{ACWP} \\
& =\mathrm{Rp} 459.231 .992,36+\mathrm{Rp} \\
& 561.712 .000,00 \\
& =\mathrm{Rp} 1.020 .943 .992,36
\end{aligned}
$$

$$
\begin{aligned}
\text { Selisih anggaran } & =\mathrm{BAC}-\mathrm{EAC} \\
& =\mathrm{Rp} 935.000 .010,00+\mathrm{Rp} \\
& 1.020 .943 .992,36 \\
& =-\operatorname{Rp} 85.943 .982,36
\end{aligned}
$$

Berdasarkan perhitungan dari indikator indikator di atas, maka kondisi yang terjadi pada proyek ini dapat diuraikan sebagai berikut :

1. Penyelesaian pekerjaan lebih lambat dari jadwal yang direncanakan yaitu selama 1 minggu

2. Berdasarkan analisa prakiraan biaya penyelesaian proyek tersebut lebih besar dari nilai anggaran yaitu sebesar $\mathrm{Rp}$ 1.020.943.992,36 dan mengalami kerugian Rp 85.943.982,36 dari anggaran yang direncanakan oleh perusahaan.

\section{KESIMPULAN DAN SARAN}

A. Kesimpulan

Berdasarkan hasil pengamatan, pengambilan data dan analisa data pada Proyek Pembangunan Perumahan Blok K Cerme Prisma Land, maka dapat ditarik kesimpulan sebagai berikut :

1. Penentuan kegiatan kritis pada Proyek Pembangunan Perumahan Blok K Cerme Prisma Land PT Cahaya Prisma Utama selesai dalam waktu 135 hari, dimana kegiatan kritisnya meliputi :

- Pengukuran \& Bowplank

- Galian Tanah Pondasi umpak batu kumbung

- Urukan tanah peninggian lantai

- Pemadatan dan Perataan Tanah

- Pas. Pondasi rolag bata putih

- Sloof Beton 15/20 K.175

- Pasangan bata putih

- Ring balok $8 / 12$

- Pasangan bata putih untuk gewel

- Pasang rangka atap Hollow Galvalum

- Pasang Spandek

- Plafond Gybsum + rangka hollow

- List Plafond Gybsum 5cm

- Cat plafond

- Pembersihan

2. Penyimpangan terhadap waktu atau Schedule Variance (SV) yang terjadi sampai pekan ke-13 adalah sebesar Rp. - 
37.213.000,40 atau sebesar -3,98 \% (nilai $\mathrm{SV}=-$ ). Hal ini berarti bahwa pelaksanaan proyek yang terjadi lebih lama dari jadwal yang telah direncanakan. Sedangkan penyimpangan terhadap biaya atau Cost Variance (CV) yang terjadi sampai pekan ke-13 adalah sebesar Rp. -47.368.494,50 atau sebesar $-5,07 \%$ (Nilai CV = - ). Hal ini menunjukkan bahwa biaya yang dikeluarkan hingga pekan ke-19 lebih besar daripada biaya yang telah direncanakan.

3. Perkiraan besarnya biaya penyelesaian proyek jika produktivitas kerja tetap adalah Rp. 1.020.943.992,36, dan pada saat proyek ditinjau, besarnya biaya yang telah dikeluarkan adalah $\mathrm{Rp}$. 561.712.000,00. Sehingga besarnya biaya yang diperluhkan untuk penyelesaian proyek yang tersisa adlaha Rp. 459.231.992,36. Sedangkan perkiraan waktu yang diperlukan untuk penyelesaian proyek Pembangunan Perumahan Blok K Cerme Prisma Land jika tingkat produktivitas dianggap tetap adalah 21 minggu. Hal ini berarti proyek mengalami keterlambatan sehingga memerlukan penambahan waktu selama 1 minggu, dimana penyelesaian proyek pada perencanaan membutuhkan waktu selama 20 minggu.

B. Saran

1. Pada pelaksanaan suatu proyek sebaiknya dilakukan pengendalian proyek sehingga dapat diketahui apakah proyek tersebut mengalami penyimpangan waktu maupun biaya yang dapat menyebabkan keterlambatan penyelesaian proyek dan biaya yang dikeluarkan lebih besar dari anggaran yang telah ditetapkan sebelumnya.

2. Dengan menggunakan metode Earned Value Method (EVM), yang didukung oleh sistem informasi yang baik, data pelaporan yang akurat, detail, dan kontinyu serta perencanaan yang baik.

3. Pengendalian waktu dan biaya sebaiknya dilakukan secara harian sehingga pengendalian waktu dan biaya lebih efektif sehingga terjadinya penyimpangan waktu dan biaya dapat dihindari sebelum mengakibatkan penyimpangan waktu dan biaya yang cukup besar

\section{DAFTAR PUSTAKA}

Basriati, Sri dan Afri Melda. (2017). Analisis Biaya Pembangunan Proyek Perumahan Menggunakan Metode PERT dan EVM Studi Kasus Perumahan D'Lion Cluster. Seminar Nasional Teknologi informasi, Komunikasi dan Industri. Riau : UIN Sultan Syarif Kasim.

Filastri. (2015). Analisa Biaya dan Waktu Proyek Pembangunan Kampus Politeknik Menggunakan Konsep Earned Value. Tugas Akhir. Makasar : Universitas Hasanuddin.

Handoko. (1999). Dasar-dasar Manajemen Produksi dan Operasi, Edisi Pertama. Yogyakarta : BPFE.

Kartikasari, Dwi. (2014). Pengendalian Biaya dan Waktu dengan Metode Earned Value Studi Kasus Proyek Struktur dan Arsitektur Production Hall-02 Pandaan. Extrapolasi Vol.7 No.2 (hal. 107-114). Surabaya : Untag.

Nurhayati. (2010). Manajemen Proyek. Yogyakarta : Graha Ilmu.

Prasetya, Eka Budhy. (2015). Aplikasi Manajemen Proyek Kontruksi dengan Metode Crictical Path dan Earned Value Management. Resistor Vol.01 No.2. Jakarta : Universitas Muhammadiyah Jakarta.

Santosa, Budi. (2009). Manajemen Proyek. Surabaya : Graha Ilmu.

Soeharto, Imam. (1995). Manajemen Proyek Dari Konseptual Sampai Operasional. Jakarta : Erlangga.

Soemardi B.W, dkk, (2007). Konsep Earned Value untuk pengelolaan Proyek Kontruksi. Bandung : Institut Teknologi Bandung. 
Sufa'atin. (2017). Penerapan Metode Earned Value Management dalam Pengendalian Biaya Proyek. Prosiding SNATIF Ke-4. Bandung : UNIKOM Bandung.

Susanty, Aries., Adi Luhung Pekerti dan Diana Puspita Sari. (2016). Analisis Kinerja Proyek Pembangunan Rumah Sakit Banyumanik II dengan Menggunakan Earned Value Analysis dan Project Evaluation Review Technique. Jurnal Teknik Industri, Vol. XI, No. 2. Semarang : Universitas Diponegoro. 